\title{
Drying characteristics of Bijapur white onion (Allium cepa L.) using solar tunnel dryer
}

\author{
- GOUDRA PRAMOD GOUDA*, C.T. RAMACHANDRA AND UDAYKUMAR NiDONI
}

Department of Processing and Food Engineering, College of Agricultural Engineering, University of Agricultural Sciences, RAICHUR (KARNATAKA) INDIA

(E mail: plgouda0426@gmail.com)

*Author for Correspondence

Research chronicle : Received : 04.02.2015; Revised : 02.05.2015; Accepted : 16.05.2015

SUMMARY :

Fresh Bijapur white onion (Allium cepa $\mathrm{L}$.) were treated with 10 per cent $\mathrm{NaCl}$ for $1 \mathrm{~h}, 0.2$ per cent KMS for 15 min and 10 per cent $\mathrm{NaCl}+0.2$ per cent KMS for 15 min and dried in solar tunnel dryer (STD) and open yard sun drying (OYSD). A comparative study was conducted to evaluate two drying methods with respect to temperature and time combinations. The sample of Bijapur white onion required 18 to $21 \mathrm{~h}$ to dry under open yardsun drying and 16 to $18 \mathrm{~h}$ in solar tunnel drier to bring down initial moisture content ranging from 599.30-774.13 per cent (d.b.) to final moisture content of 4.56-5.25 per cent (d.b.). Drying took place in the falling rate period and the Midilli and kocuck model was found to be the best fit to describe the drying behaviour of Bijapur white onion.

KEY WORDS : Bijapur white, STD and OYSD, Pre-treatment, Drying, Drying models

How to cite this paper : Gouda, Goudra Pramod, Ramachandra, C.T. and Nidoni, Udaykumar (2015). Drying characteristics of Bijapur white onion (Allium cepa L.) using solar tunnel dryer. Internat. J. Proc. \& Post Harvest Technol., 6 (1) : 87-92. 